\title{
Immobilization of Crown Flower (Calotropis gigantea) Protease Using Celite and Dextrin
}

\author{
Yuli Witono ${ }^{\# 1}$ and Lailatul Azkiyah ${ }^{\# 2}$ \\ ${ }^{\#}$ Department of Agricultural Product Technology, Faculty of Agricultural Technology, The University of Jember, Jember, 68121, Indonesia \\ E-mail: ${ }^{1}$ yuliwitono.ftp@unej.ac.id; ${ }^{2}$ lailatul.azkiyah@unej.ac.id
}

\begin{abstract}
Immobilization of crown flower (Calotropis gigantea) protease using celite and dextrin by entrapment method was investigated in this study. The influenced of celite and dextrin at the concentration $(6,8,10,15$, and 20 g/g) on enzyme production were evaluated. The optimum condition of immobilized crown flower protease was on temperature $55^{\circ} \mathrm{C}$ and $\mathrm{pH} 7.0$. Results showed that the best concentration is $8 \mathrm{~g} / \mathrm{g}$ that reached maximum specific enzyme activity was $5.69 \times 10^{-5} \mathrm{U} / \mathrm{mg}$ at celite and 3,309.10 ${ }^{-6} \mathrm{U} / \mathrm{mg}^{\circ}$ at dextrin. Immobilized enzyme is more stable than free enzyme based on the change of $\mathrm{pH}$ and temperature of environment. These results indicated that celite is better than dextrin for crown flower protease production.
\end{abstract}

Keywords - Crown flower; Calotropis gigantea protease; immobilization; celite dextrin; specific activity enzyme

\section{INTRODUCTION}

Proteases have found a wide application in several industrial process such as food, pharma, chemical, leather and silk, laundry detergents, protein recovery, degradation of glatin on Xray films and organic synthesis [1],[2],[3]. They are also used in bioremediation process [4]. They hold more than $60 \%$ of the total enzyme market in the world [5]. Proteases are found in several microorganism such as protozoa, bacteria, yeast and fungi [6] and also in several plant such as Nicotiana tobacum, Moringa oleifira, Murraya koeninguu, Coriandrum sativum and Calotropis gigantea [7],[8]. Agro waste may also be used for the production of protease enzyme. Crown flower (Calotropis gigantea) protease (CFP) is local natural resources from Indonesia that characterized in exopeptidase. CFP be used in production of protein hydrolysates as flavor enhancer.

Generally proteases are usually produced by either free or immobilized. There are several reasons for using an enzyme in an immobilized form. In addition to more convenient handling of the enzyme, it provides for its facile separation from the product, thereby minimizing or eliminating protein contamination of the product. Immobilization also facilitates the efficient recovery and reuse of costly enzymes, in many applications a condition non for economic viability, and enables their use in continuous, fixed-bed operation. A further benefit is often enhanced stability, under both storage and operational conditions, e.g., towards denaturation by heat or organic solvents or by autolysis [9].

The basic idea of this immobilization is to entrap protein in a semipermiable support material, which prevents the enzyme from leaving while allowing substrates, products and cofactor to pass through [10]. Dextrin and celite have been used extensively for microencapsulating. The aim of this study was to immobilize CFP by entrapting method using celite and dextrin as matrix agent.

\section{MATERIALS AND METHODS}

\section{A. Materials}

Protease from crown flower (Calotropis gigantea) were produced at the Biochemistry Laboratory, Faculty of Agricultural Technology, The University of Jember Indonesia. Celite and dextrin as matrix agent were purchased from Sigma Chemical Co. Chemical reagents used were Buffer phosphat $0.05 \mathrm{~N} \mathrm{pH} \mathrm{7,} \mathrm{NaCl}$, Acetone, soluble casein, TCA, $\mathrm{NaOH}, \mathrm{H}_{2} \mathrm{SO}_{4}$, Lowry reagent, selenium, and $\mathrm{H}_{2} \mathrm{O}$ from Sigma Chemical Co.

\section{B. Methods}

1) Preparation of Enzyme Extract. The protease obtained from the latex extraction of crown flower plant. Latex diluted with buffer phosphate $\mathrm{pH} 7,0(1: 1 \quad(\mathrm{v} / \mathrm{v}))$. The solution was centrifuged at $1000 \mathrm{rpm}$ for $10 \mathrm{~min}$ at room temperature. Remove the sludge, and the supernatant was 
crude protease enzyme of crown flower (CFP). Stored the enzyme at $4^{\circ} \mathrm{C}$ until be analyzed.

2) Immobilization. The $0.1 \mathrm{~g}$ of crown flower protease (CFP) was added by $5 \mathrm{ml}$ buffer phosphate $0.05 \mathrm{~N} \mathrm{pH} 7$. This suspension be added by matrix substrate (dextrin or celite) in various concentration $(6,8,10,15$, and $20 \mathrm{~g} / \mathrm{g}$ of solution) and mixed. The suspension was incubated at $55^{\circ} \mathrm{C}$ for $10 \mathrm{~min}$ and then cooled to $4^{\circ} \mathrm{C}$ for 1 hour. Added by 10 $\mathrm{ml}$ acetone and then centrifugated at $10000 \mathrm{rpm}$. For analysis supernatant was remove and sludge was dried in freeze drying for 24 hours. Both of the supernatant and sludge were used for the next analysis. Production of immoblized CFP didn't use the phase separation of supernatant and sludge, but directly dry the suspension.

3) Enzyme assay. Proteolytic activity was determined using soluble casein as a substrate based on Stoknes and Rustad $(1995)^{(11)}$ and Walker (1994) ${ }^{(12)}$. $0.01 \mathrm{~g}$ soluble casein substrat was taken in test tubes, added by buffer phosphate $0.05 \mathrm{M} \mathrm{pH} 7(3 \mathrm{ml})$, and placed in water-bath for 5 $\min$ at $37^{\circ} \mathrm{C}$. The $0.01 \mathrm{~g}$ immobilized enzyme was added to this. After $20 \mathrm{~min}$, of incubation, trichloroacetic acid (stopping solution) was added. Content was sentrifugated for 10 min. Unhydrolysed casein was removed and hydrolysed casein in supernatant was determined spectrophotometrically at absornbance $280 \mathrm{~nm}$. One unit of enzyme activity is defined as $\mu \mathrm{mol}$ of tyrosine released from $1 \mathrm{ml}$ crude enzyme in $1 \mathrm{~h}$ incubation.

4) Protein solubility. The protein solubility was determined according to the procedure of Araba and Dale $(1990)^{(13)}$. The KOH protein solubility test is based on the solubility of immobilization protease in a dilute solution of potassium hydroxide. The procedure involves the incubation of a sample with a $0.2 \% \mathrm{KOH}$ solution for $20 \mathrm{~min}$ at room temperature. Following this incubation, the sample is centrifuged and the supernatant is analyzed for the protein concentration. The solubility of the protein, expressed as a percentage, was calculated by dividing the protein content of the $\mathrm{KOH}$ extracted solution by the protein content of the original crown flower protease.

5) Determination of Total Nitrogen (Kjeldahl method). $2 \mathrm{~g}$ of sample was digested in a Kjeldahl digestion flask by boiling with $20 \mathrm{ml}$ of concentrated $\mathrm{H}$ and a Kjeldahl digestion tablet ( catalyst) until the mixture was clear. The digest was filtered into a $250 \mathrm{ml}$ volumetric flask and the solution made up to mark with distilled water and connected for distillation. Ammonia was steam distilled from of the digest to which had been added $50 \mathrm{ml}$ of $45 \%$ sodium hydroxide solution. $150 \mathrm{ml}$ of the distillate was collected in a conical flask containing $100 \mathrm{ml} 0.1 \mathrm{~N} \mathrm{HCl}$ and methyl red indicator. The ammonia that distilled into the receiving conical flask reacted with the acid and the excess acid in the flask was estimated by back titration against $2.0 \mathrm{M} \mathrm{NaOH}$ with colour change from red to yellow (end point). Determinations were made on all reagents alone (blank determinations).

$\%$ Nitrogen was calculated as follows:

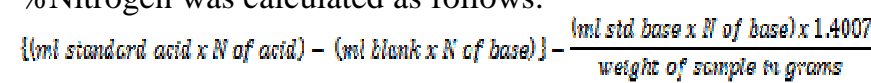

\section{RESULTS AND DISCUSSION}

Enzymes can catalyze reactions in different states: as individual molecules in solution, in aggregates with other entities, and as attached to surface (immobilized). The term of "immobilized enzymes" refers to "enzymes physically confined or localized in a certain defined region of the space with retention of their catalytic activities, and which can be used repeatedly and continuesly. Immobilized enzyme in some cases greatly improved both the technical performance of the industrial processes and their economy.

Immobilization of CFP on dextrin and celite as matrix were studied. On comparing these two methods by calculating the enzyme activity in sludge and supernatant (Fig. 1 and 2) and specific activity of immobilized enzyme (Fig. 3). The result showed that the best concentration is 8 $\mathrm{g} / \mathrm{g}$ that reached maximum specific activity of enzyme was $5.69 \times 10^{-5} \mathrm{U} / \mathrm{mg}$ at celite and $3,309.10^{-6} \mathrm{U} / \mathrm{mg}$ at dextrin (Fig. $3)$.

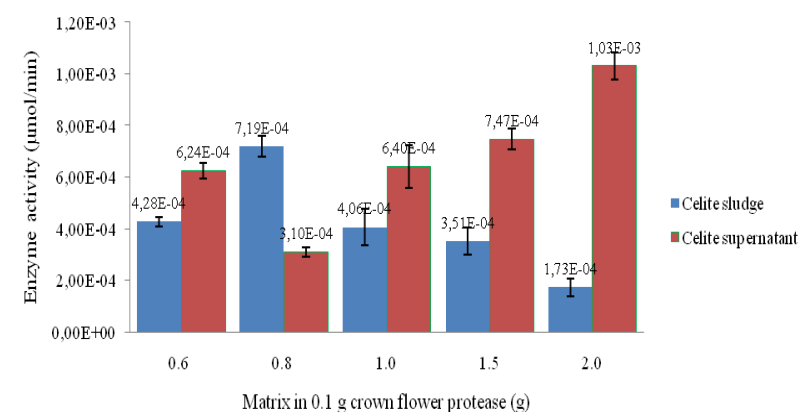

Fig. 1 Enzyme activity $(\mu \mathrm{mol} / \mathrm{min})$ of supernatant and sludge from immobilized CFP by celite matrix

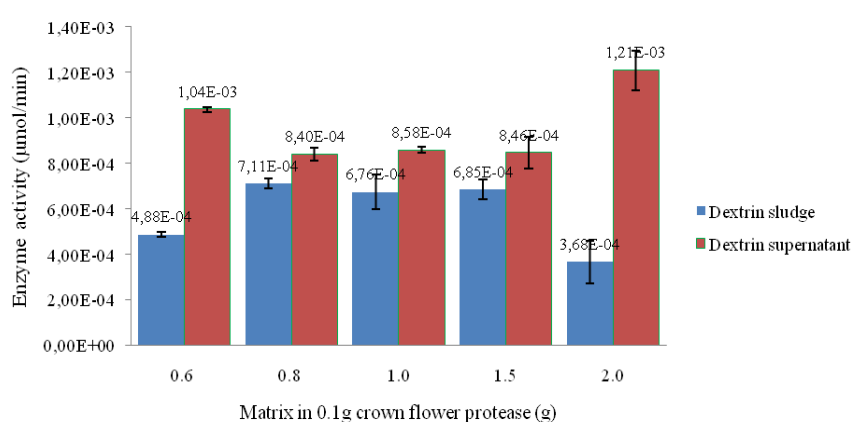

Fig. 2 Enzyme activity ( $\mu \mathrm{mol} / \mathrm{min}$ ) of supernatant and sludge from immobilized crown flower protease by dextrin matrix

In this experiment, we use free enzyme immobilized in celite and dextrin with various concentration $(0.6,0.8,1.0$, 1.5 , and $2.0 \mathrm{~g}$ in $0.1 \mathrm{~g}$ of CFP). The enzyme activity of supernatant is still higher than sludge in both celite and dextrin (Fig. 1 and 2). The specific activity of immobilized CFP used celite is better than dextrin depend on the specific enzyme activity (Fig. 3). 


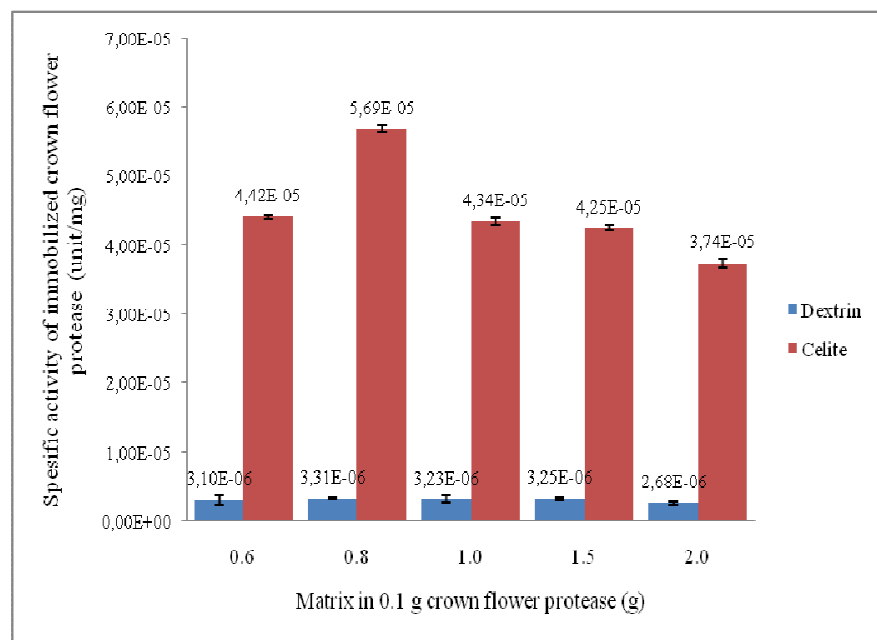

Fig. 3 Specific activity of immobilized crown flower protease (unit/mg) by celite and dextrin

Celite is highly porous diatomaceous, bioaffinity material and has been used for immobilization of lipase, polyphenol oxidases and $\beta$-galactosidase, because it is an inexpensive support, having low polarity and large adhesion area ${ }^{(14,15,16)}$. It provides resistance against high $\mathrm{pH}$ or temperature, urea, detergents and organic solvents ${ }^{(14)}$. Celite acts as an additive in sol-gel matrix for $\omega$-transaminases immobilization. It has been preferred due to its chemical inertness and interconnected pore structure ${ }^{(17)}$. It is preffered over other ideally useful porous support such as controlled porous glass. Besides these, synthetic polymers such as polyethylene and polypropylene being hydrophobic, are yet another good choice but are too costly. The yield in the case of celiteimmobilization has often been low because binding is due to be adsorption, which is a weak interaction and leaches washing.

The optimal $\mathrm{pH}$ of immobilized protease is depend on the matrix agent. Celite being an innert material, there was no change in the different $\mathrm{pH}$ reaction. Celite is a diatomics earth, which can specifically bind to the bivalent cations contain enzymes or proteins. Crown flower proteases are enzymes and henced they get adsorbed on celite.

Dextrin are a group of low molecular weight carbohydrates produced by the hydrolysis of starch. Immobilized enzyme was more efficient in the hydrolysis of starches than free enzyme. The use of dextrin as immobilization support has been very limited. Starch hybrid supports were applied for surface immobilization and entrapment of bitter gourd peroxidase. Entrapped enzyme was more stable in the presence of denaturants like urea due to internal carbohydrate moieties, while surface-immobilized enzyme had superior activity ${ }^{(18)}$. Radiation grafting of substances like acrylamide and dimethylaminoethyl methacrylate onto starch are among the widely used industrial techniques for a high product yield ${ }^{(19,20)}$.

A good immobilized will produce a good spesific activity. High activity of CFP as a catalyst in connection with metabolism of protein into amino acids that increase the total protein content in sample. Higher spesific enzyme activity, higher the total protein. In this research celite has higher specific activity than dextrin, and impact to the total protein. Total protein celite is about $4.63-12.64 \%$ higher than dextrin about $4.11-4.72 \%$ (Fig. 4).

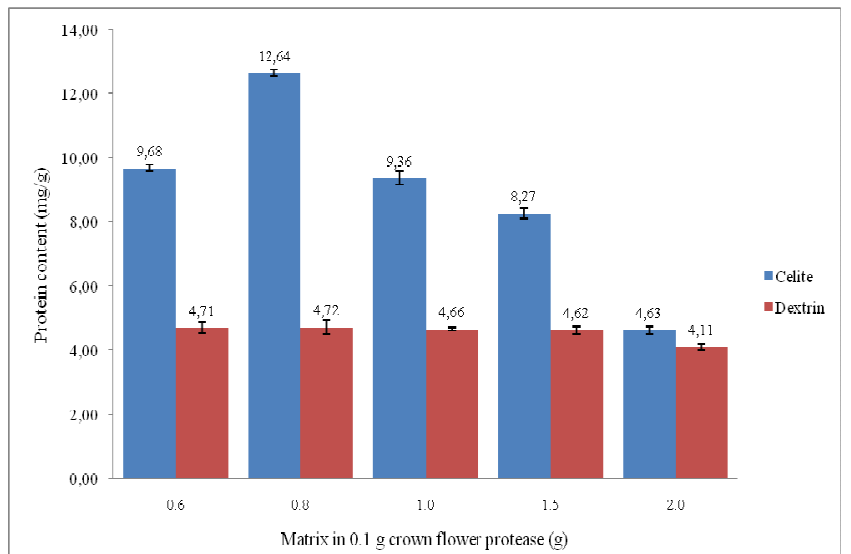

Fig. 4 Protein content $(\mathrm{mg} / \mathrm{g})$ of immobilized crown flower protease (unit/mg) by celite and dextrin

\section{CONCLUSIONS}

In conclusion, the celite entrapment is better than dextrin for immobilizing CFP production based on specific enzyme activity. The enzyme activity of supernatant is still higher than sludge in immobilized CFP, so both of them without separation phase was be used. This study illustrates a method for preparing immobilized protease isolated from crown flower (Calotropis gigante) latex agent is protected in the inner biocompatible celite and dextrin. In future, other parameters of immobilized protease can also be investigated for maximum production at a cheaper rate.

\section{ACKNOWLEDGMENT}

This Research was funded by Ministry of Research, Technology, and Higher Education, Indonesia through National Strategic Grant 2015. The authors also thank to The University of Jember for helping to publish this research.

\section{REFERENCES}

[1] MB Rao, AM Tanksale, MS Ghatge,.VV Deshpande, Microbiol..Molbiol. Rev., 1998, 62, 597-600.

[2] HS Joo; CS Chang, Enzyme microbial, 2006, 38, 176-183.

[3] R Tunga; B Shrivastava; R Banerjee, Process Biochem., 2003, 38, 1553-1558.

[4] FJ Ustariz; A Laca; LA Garcia; M Diaz, Biochem. Engr.J., 2004, 19, 147-153.

[5] Hameed, A., M.A. Natt and C.S. Evans, 1996. Short communication: Production of alkaline protease by a new Bacillus subtilis isolate for use as a bating enzyme in leather treatment. World J. Microbiol. Biotechnol, 12: 289-291.

[6] Beg QK, Gupta R and Lorenz P. Bacterial Alkaline Proteases. Molecular Approaches and Industrial Applications. Applied Microbial. Biotechnol. 2002; 59: 15-32.

[7] S. Sharmila, L. Jeyanthi Rebecca and Md Saduzzaman. Immobilization of plant protease using calcium alginate beads. 2012. Journal of Chemical and Pharmaceutical Research, 2012, 4(10):44844488.

[8] Witono et al., 2006. The Use of Ammonium Sulphate for Partial Purification of Proteases Obtained from the Latex of Milkweed Latex of Milkweed Plant (Calotropis gigantea). Jurnal Teknologi Pertanian, Vol. 7 No. 1 (April 2006) 20-26.

[9] Cao, L.; van Langen, L.; Sheldon, R.A.; Immobilised enzymes: carrier-bound of carrier-free; Curr. Opin. Biotechnol., 2003, 14, 387394. doi:10.1016/S0958-1669(03)00096-X.

[10] P Gemeiner, Enzyme Engg: Immobilized biosystems, Chichester UK: Ellis Horwood Ltd.

[11] Stoknes, I. and Rustad, T., 1995, Proteolytic Activity in Muscle from Atlantic Salmon (Salmo Solar), J. Food Sci., 60 (4), 711-714. 
[12] Walker, J.M., 1994, The Protein Protocols Handbook, Humana Press Inc. Totowa, New Jersey.

[13] Araba, M. and N. M. Dale (1990). Evaluation of protein solubility as an indicator of over processing soybean meal. Poult. Sci. 69:76-83.

[14] Khan AA, Akhtar S, Husain Q. Direct immobilization of polyphenol oxidases on celite 545 from ammonium sulphate fractionated proteins of potato (Solanum tuberosum) J Mol Catal B-Enzym. 2006; 40:58-63. doi: 10.1016/j.molcatb.2006.03.001.

[15] Liu CH, Lin YH, Chen CY, Chang JS. Characterization of Burkholderia lipase immobilized on celite carriers. J Taiwan Inst Chem E. 2009; 40:359-363. doi: 10.1016/j.jtice.2008.10.004.

[16] Ansari SA, Husain Q. Lactose hydrolysis from milk/whey in batch and continuous processes by concanavalin A-celite 545 immobilized Aspergillus oryzae $\beta$-galactosidase. Food Bioprod Process. 2011.

[17] Koszelewski D, Müller N, Schrittwieser JH, Faber K, Kroutil W. Immobilization of $\omega$-transaminases by encapsulation in a sol- gel/celite matrix. J Mol Catal B Enzym. 2010; 63:39-44. doi: 10.1016/j.molcatb. 2009.12001

[18] Mislovicová D, Masarova J, Vikartovska A, Germeiner P, Michalkova E. Biospecific immobilization of mannan-penicillin G acylase neoglycoenzyme on Concanavalin A-bead cellulose. J Biotechnol. 2004; 110:11-19. doi: 10.1016/j.jbiotec.2004.01.006.

[19] Dung NA, Huyen ND, Hang ND, Canh TT. Immobilization of urease on grafted starch by radiation method. Radiat Phys Chem. 1995; 46:1037-1042. doi: 10.1016/0969-806X(95)00316-P.

[20] Raafat AI, Araby E, Lotfy S. Enhancement of fibrinolytic enzyme production from Bacillus subtilis via immobilization process onto radiation synthesized starch/dimethylaminoethyl methacrylate hydrogel. Carbohyd Polym. 2011; 87:1369-1374. doi: 10.1016/j.carbpol.2011.09.029. 